\title{
Metabolic fate of orally administered cGMP in rats
}

\author{
Elaine Liong ${ }^{*}$, Christopher Graul, Samuel Rivers, Marco Kessler, Gerhard Hannig, Inmaculada Silos-Santiago \\ From 6th International Conference on cGMP: Generators, Effectors and Therapeutic Implications \\ Erfurt, Germany. 28-30 June 2013
}

\section{Background}

Activation of membrane guanylate cyclase type $\mathrm{C}(\mathrm{GC}-\mathrm{C})$ on the luminal surface of the intestinal epithelium by GC$\mathrm{C}$ agonists results in an increase in both intracellular and extracellular levels of cyclic guanosine monophosphate (cGMP). Elevation in intracellular cGMP results in the secretion of chloride and bicarbonate anions into the intestinal lumen through the activation of the cystic fibrosis transmembrane conductance regulator (CFTR) ion channel. Physiologically, this results in increased intestinal fluid and accelerated transit. Furthermore, an accompanying increase in the luminal and submucosal concentration of cGMP is observed as intracellular cGMP is transported out of epithelial cells. In animal models, decreased activity of pain-sensing afferent fibers is likely mediated by increased extracellular cGMP in the submucosa [1]. Compared to the pharmacological effects elicited by the increase in cGMP, less is known about the distribution and metabolic fate of this second messenger that is transported out into the luminal space.

\section{Results and conclusion}

We used radiolabeled 14C-cGMP to assess the presence and metabolism of cGMP following oral administration in different regions of the gastrointestinal tract in rats, as well as in plasma and urine. In tracking the levels of 14CcGMP and its metabolites we developed a better understanding of the fate of orally dosed cGMP in the intestinal tract, which has implications for the mechanism of action of cGMP in decreasing gastrointestinal pain. Specifically, we hypothesize that cGMP may act on intestinal afferent fibers while travelling along the small intestine whose projections converge on second order neurons that also receive input from colonic afferents, thus affecting their function. In this context, we showed that more than $50 \%$ of the dosed cGMP is available in the small intestine 2 hours after dosing. Little/no 5'GMP or other metabolites

\footnotetext{
* Correspondence: eliong@ironwoodpharma.com

Ironwood Pharmaceuticals, Cambridge, MA 02142, USA
}

were detected in the luminal contents. In contrast, 40-50\% of cGMP metabolites were found in tissue samples.

Published: 29 August 2013

\section{Reference}

1. Castro J, Martin C, Hughes PA, Silos-Santiago A, Kurtz CB, Blackshaw LA, Brierley SM: A novel role of cyclic GMP in colonic sensory neurotransmission in healthy and TNBS-treated mice. Gastroenterology 2011, 140:538.

doi:10.1186/2050-6511-14-S1-P39

Cite this article as: Liong et al:: Metabolic fate of orally administered cGMP in rats. BMC Pharmacology and Toxicology 2013 14(Suppl 1):P39.

\section{Submit your next manuscript to BioMed Central and take full advantage of: \\ - Convenient online submission \\ - Thorough peer review \\ - No space constraints or color figure charges \\ - Immediate publication on acceptance \\ - Inclusion in PubMed, CAS, Scopus and Google Scholar \\ - Research which is freely available for redistribution

C 2013 Liong et al; licensee BioMed Central Ltd. This is an Open Access article distributed under the terms of the Creative Commons Attribution License (http://creativecommons.org/licenses/by/2.0), which permits unrestricted use, distribution, and reproduction in any medium, provided the original work is properly cited. 